\title{
Epidemiological Effect of Gene Deployment Strategies on Bacterial Blight of Rice
}

\author{
Hafiz U. Ahmed, Maria R. Finckh, Rizal F. Alfonso, and Christopher C. Mundt
}

Entomology and Plant Pathology Division, International Rice Research Institute, P.O. Box 933, 1099 Manila, Philippines.

Current address of H. U. Ahmed: Division of Plant Pathology, Bangladesh Rice Research Institute, Joydebpur, Gazipur 1701, Bangladesh; M. R. Finckh: Gruppe Phytomedizin, Swiss Federal Institute of Technology, ETH Zentrum/LFW, Universitaetsstrasse 2, 8092 Zürich, Switzerland; and C. C. Mundt: Department of Botany and Plant Pathology, 2082 Cordley Hall, Oregon State University, Corvallis 973312902.

Accepted for publication 20 September 1996.

\begin{abstract}
Ahmed, H. U., Finckh, M. R., Alfonso, R. F., and Mundt, C. C. 1997. Epidemiological effect of gene deployment strategies on bacterial blight of rice. Phytopathology 87:66-70.

Experiments were conducted in farmers' fields at two locations of the irrigated lowlands of Laguna province in southern Luzon island, Philippines, during the wet seasons of 1993 and 1994. Nine rice populations were studied including pure stands, two-component mixtures, two-gene

blight. The area under the disease progress curve (AUDPC) of both gene combinations studied was significantly less than the single most effective gene of each combination deployed singly. A mixture of a susceptible and a resistant line expressed an AUDPC significantly less than the mean of its component pure stands, but two other mixtures did not. The cultivar IR20, which contains both $\mathrm{Xa}-4$ and partial resistance, reduced the AUDPC by about two-thirds as compared with IR-BB4, which contains $X a-4$ and little or no partial resistance.
\end{abstract} combinations of backcrossed lines containing varying combinations of the bacterial blight resistance genes $X a-4, x a-5$, and $X a-10$, and a nonisogenic cultivar containing $X a-4$ and partial resistance to bacterial
Additional keywords: Oryza sativa, Xanthomonas oryzae pv. oryzae.
Bacterial blight of rice (Oryza sativa L.), caused by Xanthomonas oryzae pv. oryzae, is a serious disease of global importance. No effective and economical chemical control methods are available (3). The major means of management is through the use of resistant cultivars. Eighteen bacterial blight resistance genes have been registered (12), and several resistance genes have been incorporated into agronomically suitable rice cultivars (29). However, gene-for-gene relationships have been suggested in the bacterial blight pathosystem $(20,21,22,23)$. Deployment of simply inherited, uniform resistance over vast areas has decreased the effectiveness of resistance, because of selection for corresponding, virulent pathotypes $(20,22,23)$.

Deployment methods to increase the durability of host plant resistance have often been discussed $(13,19,24,33,37)$, but rarely have direct field comparisons been made of different deployment methods for a given disease. Information on gene deployment is largely lacking for the bacterial blight disease of rice (31). Thus, we conducted field experiments to determine the epidemiological effect of single genes, two-gene combinations, two-way mixtures of single-gene lines, and a line with partial resistance on the temporal progression of bacterial blight.

\section{MATERIALS AND METHODS}

Establishment of treatments. During the wet seasons of 1993 and 1994, identical experiments were conducted in Calauan and Mabitac in the irrigated lowlands of Laguna province in southern Luzon island, Philippines. Both locations are known to be endemic for high incidence of bacterial blight. Surveys conducted in

Corresponding author: C. C. Mundt; E-mail address: mundtc@bcc.orst.edu

Publication no. P-1996-1118-01R

(c) 1997 The American Phytopathological Society farmers' fields in 1992 (C. M. Vera-Cruz and M. R. Finckh, unpublished data) indicated that 97 and $40 \%$ of the isolates were virulent to both bacterial blight resistance genes $\mathrm{Xa}-4$ and $\mathrm{Xa}-\mathrm{IO}$ in Mabitac and Calauan, respectively. The remainder of the isolates were virulent on $X a-4$, but not $X a-10$. Virulence against $x a-5$ was not detected in the surveys. The experiments were conducted in the same paddy in Mabitac in both years. However, in Calauan, the 1994 experiment was conducted in the paddy adjacent to the 1993 experiment.

The nine rice populations that were studied consisted of pure stands and mixtures of different rice genotypes (Table 1). Seven of these populations were pure stands, two-gene mixtures, and twogene combinations of backcrossed lines containing varying assemblages of the bacterial blight resistance genes $X a-4, x a-5$, and $X a-10$. These lines were developed by backcrossing resistance sources four times to the recurrent parent IR24, which is susceptible to all known Philippine isolates of the pathogen (29). The remaining two populations were a pure stand and a mixture containing the cultivar IR20, which possesses the $\mathrm{Xa}-4$ major gene as well as a considerable level of partial resistance.

TABLE 1. Resistance genes of rice populations tested for their impact on epidemic development of bacterial blight in field experiments at two locations in the Philippines

\begin{tabular}{ll}
\hline Rice population & \multicolumn{1}{c}{ Resistance gene(s) } \\
\hline IR-BB4 & $X a-4$ \\
IR-BB5 & $x a-5$ \\
IR-BB10 & $X a-10$ \\
IR20 & $X a-4$ and partial resistance \\
IR-BB4/5 & Combination of $X a-4$ and $x a-5$ \\
IR-BB4/10 & Combination of $X a-4$ and $X a-10$ \\
IR-BB4 + IR-BB5 & Mixture of $X a-4+x a-5$ \\
IR-BB4 + IR-BB10 & Mixture of $X a-4+X a-10$ \\
IR-BB5 + IR20 & Mixture of $x a-5+X a-4$ and partial resistance \\
\hline
\end{tabular}


While the 1993 trials were being conducted, it was found that only two-thirds of plants in our seed stocks of the IR-BB4/10 putative combination possessed both genes for resistance; the remaining plants possessed either one or neither of the two resistance genes. Seed stocks used in 1994 were breeding true for the presence of both resistance genes, as indicated by greenhouse inoculations.

In each location, the rice populations were grown in $4 \times 4-\mathrm{m}$ plots in a randomized complete block design with four replications. A border of $4 \mathrm{~m}$ was planted between all plots with the cultivar IR48 in 1993 and IR54 in 1994, both of which provide some resistance against $X$. oryzae pv. oryzae races that can attack rice genotypes with resistance genes $\mathrm{Xa}-4$ and $\mathrm{Xa}-10$ (11).
Seedlings of all cultivars were grown in wet seed beds in a screenhouse for 3 to 4 weeks at the International Rice Research Institute. Seedlings were transplanted into field plots on 29 July 1993 and 22 July 1994 in Calauan, and on 5 August in both years in Mabitac. Surrounding fields were being planted by farmers at this time. Two to four seedlings per hill were transplanted, with 20 $\mathrm{cm}$ between hills. Mixtures were established by transplanting the same number of seedlings of each genotype in the same hill. The 1993 experiment in Calauan was lost to flooding and a subsequent invasion of the golden snail (Pomacea sp.) and was transplanted again on 6 September. Because of insufficient seed of IR-BB5, one replication in the 1993 Calauan experiment was without the

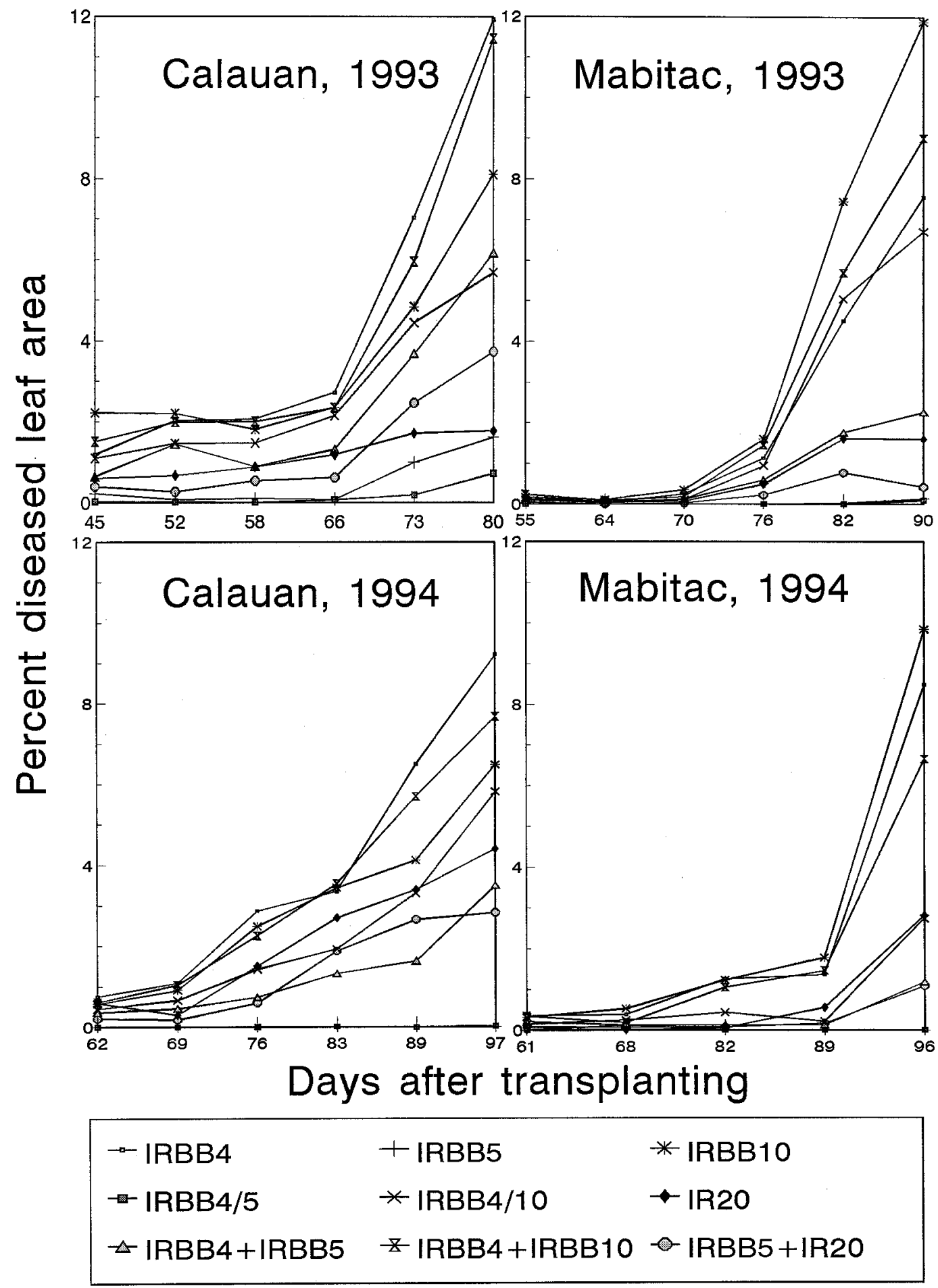

Fig. 1. Disease progress curves of bacterial blight on rice populations in farmers' fields at two locations in the Philippines. Table 1 has the description of the rice populations. 
pure stand of IR-BB5 and the IR20 + IR-BB5 mixture. In both locations, missing hills due to snail and other damage were replaced with spare seedlings (mixtures) or by dividing hills within the plots (pure stands).

In Calauan, the plots were fertilized with $126 \mathrm{~kg} / \mathrm{ha}$ each of $\mathrm{N}$, $\mathrm{P}_{2} \mathrm{O}_{5}$, and $\mathrm{K}_{2} \mathrm{O}$. In Mabitac, the plots received 107, 13, 13, and 44 $\mathrm{kg} / \mathrm{ha}$ of $\mathrm{N}, \mathrm{P}_{2} \mathrm{O}_{5}, \mathrm{~K}_{2} \mathrm{O}$, and $\mathrm{S}$, respectively. Moluscacides and insecticides were applied as needed. When possible, golden snails were removed by hand until seedlings were established. Handweeding was performed two to three times per season.

Disease assessments. The experiments and the bordering fields were scouted weekly for the appearance of bacterial blight symptoms. Starting the week following the first appearance of disease symptoms (45 to 62 days after transplanting), disease severity was assessed weekly until the plants became too senescent to allow for reliable distinction of bacterial blight lesions (about 90 to 97 days after transplanting). An exception was at Calauan in 1993, when assessments were begun at 45 days after transplanting despite the earlier appearance of bacterial blight.

For disease assessments, 10 hills were picked randomly from each plot by reaching in blindly from the edge so as to avoid spreading the disease by walking inside the plots. Later in the epidemics, when virtually all hills showed infection, hills were also picked in the center. Each of two observers recorded the percent leaf area covered by bacterial blight lesion(s) for all leaves in five hills per plot. Means over 10 hills were calculated to give percent diseased leaf area per plot. The data were used to calculate the area under disease progress curve (AUDPC) for each plot, following Shaner and Finney (34).

Data analyses. AUDPC data were subjected to analyses of variance for a randomized complete block design using the General Linear Models Procedure (PROC GLM) of the Statistical Analysis System (SAS Institute Inc., Cary, NC). Sums of squares for host population were divided into eight preplanned linear contrasts. Lines with resistance gene combinations were contrasted with the most effective single gene contained in each of the two combinations to determine if there were interactions between the two genes for disease reaction. Each of the three mixtures was contrasted with the mean of its component pure stands to determine if mixing host genotypes resulted in altered epidemic development as compared with the components grown separately in pure stand.

Initial analyses of AUDPC data were conducted on individual experiments, as well as combined over locations and years, to determine the relative merit of conducting separate versus combined analyses. Exploratory analyses indicated heterogeneous variances that could not be corrected with standard transformations. Therefore, each datum was weighted by the inverse of the variance of its treatment mean, using the WEIGHT option of PROC GLM, to obtain the best linear unbiased estimators. Interactions of host population with location and year were all highly significant.

TABLE 2. Area under disease progress curve (percent days) for bacterial blight of rice on nine host populations grown in farmers' fields at two locations in the Philippines during the wet seasons of 1993 and 1994

\begin{tabular}{lrrrrrr}
\hline & \multicolumn{4}{c}{ Location } & \\
\cline { 2 - 3 } & \multicolumn{2}{c}{ Calauan } & & \multicolumn{2}{c}{ Mabitac } & \\
\cline { 2 - 3 } \cline { 5 - 6 } Rice population $^{\mathrm{a}}$ & \multicolumn{1}{c}{1993} & 1994 & & 1993 & 1994 & Grand mean \\
\hline IR-BB4 & 143.1 & 130.0 & & 70.9 & 57.8 & 100.5 \\
IR-BB5 & 15.3 & 0.0 & & 0.6 & 0.1 & 4.1 \\
IR-BB10 & 114.6 & 97.9 & & 113.0 & 66.6 & 98.0 \\
IR-BB4/5 & 4.7 & 0.2 & & 0.5 & 0.01 & 1.3 \\
IR-BB4/10 & 90.7 & 71.5 & & 69.3 & 18.9 & 62.6 \\
IR20 & 39.6 & 70.2 & & 22.2 & 14.4 & 36.6 \\
IR-BB4 + IR-BB5 & 66.3 & 40.9 & & 26.5 & 8.3 & 35.6 \\
IR-BB4 + IR-BB10 & 131.4 & 112.8 & & 87.4 & 47.7 & 94.8 \\
IR-BB5 + IR20 & 41.9 & 46.8 & & 8.9 & 7.0 & 26.2 \\
\hline
\end{tabular}

a Table 1 has the description of the rice populations.
However, the mean square for each of these interactions was less than $10 \%$ of the mean square for the main effect of host population, which justifies the use of a combined analysis (9).

\section{RESULTS}

Disease. Isolates collected from within and around the experiments indicated that $90 \%$ or more of $X$. oryzae pv. oryzae isolates were virulent against both $X a-4$ and $X a-10$, but not against $x a-5$ (M. R. Finckh, unpublished data). Thus, our plots were exposed to a pathogen population consisting primarily of isolates with combined virulence against two of the resistance genes under study, but few or no isolates were virulent against rice genotypes possessing the third gene.

Disease began early and progressed steadily throughout the season in both years at Calauan. Because of the need to transplant a second time at Calauan in 1993, the surrounding commercial fields were already diseased at the time of transplanting, resulting in a higher level of disease at the time of the first assessment in comparison with the other three experiments (Fig. 1). At Mabitac, epidemics started later and initially progressed slower than at $\mathrm{Ca}-$ lauan. Later in the season, however, epidemic progression became steeper at Mabitac than at Calauan (Fig. 1).

Effectiveness of the resistance gene deployment strategies varied (Tables 2 and 3). AUDPCs of both gene combinations were significantly less than the single most effective gene of each combination deployed singly in pure stand. Although stocks of our IRBB4/10 combination in 1993 were impure, results were similar when pure stocks were used in 1994. Only one of three mixtures significantly reduced the AUDPC relative to the mean of the pure stand components. Resistance genes deployed in two-gene combinations resulted in significantly less disease than when the same two genes were deployed as two-component mixtures. IR20, which contains both $\mathrm{Xa}-4$ and partial resistance, reduced the AUDPC by about two-thirds as compared with IR-BB4, which contains $\mathrm{Xa}-4$ and little or no partial resistance.

\section{DISCUSSION}

Our experiments provided an opportunity to compare different resistance genes deployed in a similar genetic background as single genes, gene combinations, and mixtures in the same experiments. Our results suggest that, for bacterial blight, resistance gene combinations and some mixtures can increase the effectiveness of resistance genes. Gene combinations were more effective than mixtures for the limited number of populations tested in this study. The partial resistance of IR20 provided very significant disease reductions relative to IRBB-4. This result is based on only one partially resistant genotype, and this cultivar was not near-

TABLE 3. Significance of linear contrasts for area under disease progress curve (AUDPC, percent days) for bacterial blight on nine rice populations ${ }^{\mathrm{a}}$ grown in farmers' fields at two locations in the Philippines during the wet seasons of 1993 and 1994

\begin{tabular}{lrc}
\hline Linear contrast & AUDPC & $P$ value \\
\hline IR-BB4 vs. IR-BB10 & 100.5 vs. 98.0 & 0.7558 \\
$\begin{array}{l}\text { IR-BB4 + IR-BB10 mixture vs. mean of IR-BB4 } \\
\quad \text { and IR-BB10 pure stands }\end{array}$ & 94.8 vs. 99.2 & 0.5393 \\
IR-BB4/10 combination vs. IR-BB10 pure stand & 62.6 vs. 98.0 & 0.0001 \\
IR-BB4 + IR-BB5 mixture vs. mean of IR-BB4 & & \\
$\quad$ and IR-BB5 pure stands & 35.6 vs. 52.3 & 0.0020 \\
IR-BB4 vs. IR20 & 100.5 vs. 36.6 & 0.0001 \\
IR-BB5 + IR20 mixture vs. mean of IR-BB5 and & & \\
$\quad$ IR20 pure stands & 26.2 vs. 20.3 & 0.1429 \\
IR-BB4/5 vs. IR-BB5 & & 0.0412 \\
Mean of IR-BB4 + IR-BB10 and IR-BB4 + IR- & & \\
$\quad$ BB5 mixtures vs. mean of IR-BB4/10 and IR- & & \\
$\quad$ BB4/5 combinations & 60.5 vs. 32.0 & 0.0001 \\
\hline
\end{tabular}

a Table 1 has the description of the rice populations. 
isogenic to the other genotypes included in the experiment. However, previous studies have indicated a substantial impact of partial resistance on epidemic development of bacterial blight of rice $(11,14)$. Our study addressed the effects of resistance gene deployment on temporal epidemic progression only. In determining the most useful approaches to resistance gene deployment, ease of breeding and effect on pathogen evolution will ultimately need to be considered.

We had no reason to expect, a priori, that the resistance genes we studied would or would not interact favorably for disease control when combined in a single genotype. The existence of "residual effects" of resistance genes has, in general, been a controversial and difficult area of study (30). However, the fact that both gene combinations provided a positive synergism for disease reduction in our study indicates promise for the use of resistance gene combinations against bacterial blight of rice, as has been the case for wheat (Triticum aestivum) rusts (Puccinia spp.) (15,32, 35). Interestingly, greenhouse inoculations of IR-BB4/10 with nine compatible bacterial blight isolates did not show a synergistic effect on lesion length of bacterial blight (38). Infection efficiency and latent period may be important determinants of rates of epidemic development, and are not necessarily accounted for by lesion length measurements.

These experiments identified different effects of three mixtures on bacterial blight severity. Reddy and Nayak (31) found significant reductions of bacterial blight severity in mixtures of a resistant and a susceptible rice genotype, as in our study when resistant (IR-BB5) and susceptible (IR-BB4) backcrossed rice lines were deployed in a 1:1 mixture. In contrast, the IR-BB4 + IR-BB10 mixture provided no reduction in the AUDPC. This mixture was ineffective probably because prevalent isolates in both locations and years were virulent against both IR-BB4 and IR-BB10, and genetic backgrounds of these two lines were very similar. The mixture containing an effective resistance gene (IR-BB5) and a genotype with partial resistance (IR20) did not reduce epidemic progression of bacterial blight relative to the mean of its component pure stands. Though the epidemiological interaction of partial resistance and mixtures has been shown to be complex $(4,10,28)$, one might expect that partial resistance would complement the epidemiological effectiveness of host diversity. However, IR20 was noticeably taller and had greater leaf area in mixture than did IR-BB5. Thus, the proportion of IR20 in this mixture was significantly greater than $1: 1$, which would increase the overall disease severity level of the mixture. Further, plant competition can influence susceptibility of a genotype to disease $(5,6)$, and such a competitive effect could also have played a role in the IR-BB5 + IR20 mixture, in which IR20 was more competitive than IR-BB5.

Mixtures provided less control of bacterial blight of rice than has been the case for some other diseases. Intraspecific host mixtures have been shown to provide greater disease reductions against wind-dispersed pathogens of small grains $(2,25,26,36)$ than we found for bacterial blight, which is caused by a splashdispersed pathogen. Splash dissemination results in steep dispersal gradients $(8,18)$, increased autoinfection (27) and, hence, a reduction in the efficacy of mixtures for disease control $(7,27)$. Further, diseases with large lesions, as is the case for bacterial blight of rice, are less effectively controlled by mixtures than are diseases with smaller lesions $(16,17)$. Finally, we tested only two-way mixtures in this study, and increased disease control might be seen with more complex mixtures.

A significant level of bacterial blight developed on IR-BB5 and IR-BB4/5 in Calauan in 1993, suggesting that resistance gene $x a-5$ is likely to "break down" once deployed on a large scale. Adhikari et al. (1) suggested the deployment of $x a-5$ in southeast and northeast Asia, because the matching virulence had not been isolated from these regions. However, the effectiveness of the $x a-5$ resistance gene might be jeopardized if deployed uniformly and extensively in these regions.
Our trials in farmers' fields showed the epidemiological value of deployment of a rice genotype with partial resistance, gene combinations, and a mixture of a resistant and a susceptible line against bacterial blight disease of rice. Therefore, additional options are available to plant breeders for management of genetic resistance to bacterial blight, even after individual genes have been "defeated" by the pathogen.

\section{ACKNOWLEDGMENTS}

This research was conducted under a scientific agreement between the International Rice Research Institute (IRRI) and Oregon State University, and was supported in part by a grant from the United Nations Development Programme to the IRRI.

\section{LITERATURE CITED}

1. Adhikari, T. B., Vera Cruz, C. M., Zhang, Q., Nelson, R. J., Skinner, D. Z., Mew, T. W., and Leach, J. E. 1995. Genetic diversity of Xanthomonas oryzae pv. oryzae in Asia. Appl. Environ. Microbiol. 61:966-971.

2. Browning, J. A., and Frey, K. J. 1969. Multiline cultivars as a means of disease control. Annu. Rev. Phytopathol. 7:355-382.

3. Devadath, S. 1989. Chemical control of bacterial blight of rice. Pages 89-98 in: Bacterial Blight of Rice. International Rice Research Institute, Manila, Philippines.

4. Elliot, V. 1981. The influence of the number of component lines and of rate-limiting resistance on the epidemiology of multiline cultivars. Ph.D. thesis. The Pennsylvania State University, College Park.

5. Finckh, M. R., and Mundt, C. C. 1992. Plant competition and disease in genetically diverse wheat populations. Oecologia 91:82-92.

6. Finckh, M. R., and Mundt, C. C. 1992. Stripe rust, yield, and plant competition in wheat cultivar mixtures. Phytopathology 82:905-913.

7. Fitt, B. D. L., and McCartney, H. A. 1986. Spore dispersal in relation to epidemic models. Pages 311-345 in: Plant Disease Epidemiology. Vol. 1. K. J. Leonard and W. E. Fry, eds. Macmillan Publishing, New York.

8. Fitt, B. D. L., McCartney, H. A., and Walklate, P. J. 1989. The role of rain in dispersal of pathogen inoculum. Annu. Rev. Phytopathol. 27:241270.

9. Gomez, K. A., and Gomez, A. A. 1984. Statistical Procedures for Agricultural Research. 2nd ed. John Wiley \& Sons, New York.

10. Jeger, M. J., Griffiths, E., and Jones, D. G. 1981. Disease progress of non-specialized pathogens in intraspecific mixed stands of cereal cultivars. I. Models. Ann. Appl. Biol. 98:187-198.

11. Khush, G. S., Mackill, D. J., and Sidhu, G. S. 1989. Breeding rice for resistance to bacterial blight. Pages 207-217 in: Bacterial Blight of Rice. International Rice Research Institute, Manila, Philippines.

12. Kinoshita, T. 1991. Report of the committee on gene symbolization, nomenclature and linkage groups. Rice Genet. Newsl. 8:2-37.

13. Kiyosawa, S. 1989. Breakdown of blast resistance in relation to general strategies of resistance gene deployment to prolong effectiveness of disease resistance of plants. Pages 251-283 in: Plant Disease Epidemiology. Vol. 2. K. J. Leonard and W. E. Fry, eds. McGraw-Hill Book Co., New York.

14. Koch, M. F., and Parlevliet, J. E. 1991. Genetic analysis of, and selection for, factors affecting quantitative resistance to Xanthomonas campestris pv. oryzae in rice. Euphytica 53:235-245.

15. Kolmer, J. A., Dyck, P. L., and Roelfs, A. P. 1991. An appraisal of stem and leaf rust resistance in North American hard red spring wheats and the probability of multiple mutations to virulence in populations of cereal rust fungi. Phytopathology 81:237-239.

16. Lannou, C., de Vallavieille-Pope, C., Biass, C., and Goyeau, H. 1994. The efficacy of mixtures of susceptible and resistant hosts to two wheat rusts of different lesion size: Controlled condition experiments and computerized simulations. J. Phytopathol. 140:227-237.

17. Lannou, C., de Vallavieille-Pope, C., and Goyeau, H. 1994. Host mixture efficacy in disease control: Effects of lesion growth analyzed through computer-simulated epidemics. Plant Pathol. 43:651-662.

18. Madden, L. V. 1992. Rainfall and the dispersal of fungal spores. Adv. Plant Pathol. 8:39-79.

19. Marshall, D. R. 1989. Modeling the effects of multiline varieties on the population genetics of plant pathogens. Pages 284-317 in: Plant Disease Epidemiology. Vol. 2. K. J. Leonard and W. E. Fry, eds. McGraw-Hill Book Co., New York.

20. Mew, T. W. 1987. Current status and future prospects of research on bacterial blight of rice. Annu. Rev. Phytopathol. 25:359-382.

21. Mew, T. W. 1989. An overview of the world bacterial blight situation. Pages 7-12 in: Bacterial Blight of Rice. International Rice Research Institute, Manila, Philippines. 
22. Mew, T. W., Vera Cruz, C. M., and Medalla, E. S. 1992. Changes in race frequency of Xanthomonas oryzae pv. oryzae in response to rice cultivars planted in the Philippines. Plant Dis. 76:1029-1032.

23. Mew, T. W., Vera Cruz, C. M., and Reyes, R. C. 1982. Interaction of Xanthomonas campestris pv. oryzae and a resistant rice cultivar. Phytopathology 72:786-789.

24. Mundt, C. C. 1994 . Techniques to manage pathogen coevolution with host plants to prolong resistance. Pages 193-205 in: Rice Pest Science and Management. P. S. Teng, K. L. Heong, and K. Moody, eds. International Rice Research Institute, Los Banos, Philippines.

25. Mundt, C. C. 1994. Use of host genetic diversity to control cereal diseases: Implications for rice blast. Pages 293-308 in: Rice Blast Disease. R. S. Zeigler, S. A. Leong, P. S. Teng, eds. CAB International, Oxon, United Kingdom, and International Rice Research Institute, Los Banos, Philippines.

26. Mundt, C. C., and Browning, J. A. 1985. Genetic diversity and cereal rust management. Pages 527-560 in: The Cereal Rusts. Vol. 2. A. P. Roelfs and W. R. Bushnell, eds. Academic Press, Orlando, FL.

27. Mundt, C. C., and Leonard, K. J. 1986. Analysis of factors affecting disease increase and spread in mixtures of immune and susceptible plants in computer-simulated epidemics. Phytopathology 76:832-840.

28. Newton, A. C., and Thomas, W. T. B. 1992. The effect of specific and non-specific resistance in mixtures of barley genotypes on infection by mildew (Erysiphe graminis f. sp. hordei) and on yield. Euphytica 59:73-81.

29. Ogawa, T., Yamamoto, T., Khush, G. S., and Mew, T. W. 1991. Breeding of near-isogenic lines of rice with single genes for resistance to bacterial blight pathogen (Xanthomonas campestris pv. oryzae). Jpn. J. Breed.
41:523-529.

30. Pedersen, W. L., and Leath, S. 1988. Pyramiding major genes for resistance to maintain residual effects. Annu. Rev. Phytopathol. 26:369-378.

31. Reddy, P. R., and Nayak, P. 1984. Progress of bacterial leaf blight disease in mixed population of resistant and susceptible rice cultivars. Acta Phytopathol. Acad. Sci. Hung. 19:285-290.

32. Samborski, D. J., and Dyck, P. L. 1982. Enhancement of resistance to Puccinia recondita by interactions of resistance genes in wheat. Can. J. Plant Pathol. 4:152-156.

33. Schafer, J. F., and Roelfs, A. P. 1985. Estimated relation between numbers of urediniospores of Puccinia graminis f. sp. tritici and rates of occurrence of virulence. Phytopathology 75:749-750.

34. Shaner, G., and Finney, R. E. 1977. The effect of nitrogen fertilization on the expression of slow-mildewing resistance in Knox wheat. Phytopathology 67:1051-1056.

35. Watson, I. A. 1970. Changes in virulence and population shifts in plant pathogens. Annu. Rev. Phytopathol. 8:209-230.

36. Wolfe, M. S. 1985. The current status and prospects of multiline cultivars and variety mixtures for disease resistance. Annu. Rev. Phytopathol. 23:251-273.

37. Wolfe, M. S. 1992. Barley diseases: Maintaining the value of our varieties. Pages 1055-1067 in: Barley Genetics VI. L. Munck, ed. Munksgaard International Publishers, Copenhagen.

38. Yoshimura, S., Yoshimura, A., Iwata, N., McCouch, S. R., Abenes, M. L., Baraoidan, M. R., Mew, T. W., and Nelson, R. J. 1995. Tagging and combining bacterial blight resistance genes in rice using RAPD and RFLP markers. Mol. Breed. 1:375-387. 